\title{
KAJIAN KETERSEDIAAN AIR DAN POTENSI DAYA LISTRIK YANG DIHASILKAN PADA RENCANA PEMBANGUNAN PLTMH KEBONGEMBONG KABUPATEN KENDAL
}

\author{
Muji Rifai \\ Program Studi Teknik Sipil, Universitas Sebelas Maret \\ J1. Ir. Sutami 36 A, Kentingan Surakarta 57126; Telp. (0271) 634524, Fax 662118 \\ Email: mujirifai@staff.uns.ac.id
}

\begin{abstract}
Population growth and the increase in the socio-economy of society have led to increased demand for electricity. Indonesia's location which is on the equator makes it a country that has a wealth of tropical rain forests, where this condition provides the potential for abundant water resources. Management of water resources can be realized by converting water into electrical energy better and more efficiently. Micro bydro power plant (MHP) is an alternative source of electrical energy that can be developed at this time. In an effort to participate in the national electricity sector, a PLTMH will be built in Kebongembong Village, Pageruyung District, Kendal Regency. The main elements in PLTMH include water as an energy source, turbines and generators. The energy source in the form of water must have a certain flow rate and head, which will determine the amount of electrical power produced. Analysis of water availability and the building for taking PLTMH Kebongembong is located in the Lampir River. In calculating the potential electric power that can be generated PLTMH will use the smallest discharge from Q-90 from the Lampir River, which is $1.2 \mathrm{~m}^{3} /$ second. The amount of potential electrical power that can be generated by PLTMH Kebongembong is $370 \mathrm{~kW}$.
\end{abstract}

Keywords: Discharge, electrical power, micro hydro power plant, water

\begin{abstract}
Abstrak
Pertumbuhan penduduk dan peningkatan sosial ekonomi masyarakat, menyebabkan meningkatnya kebutuhan listrik. Letak Indonesia yang berada di daerah khatulistiwa menjadikannya negara yang memiliki kekayaan hutan hujan tropis, dimana kondisi ini memberikan potensi sumber daya air yang melimpah. Pengelolaan terhadap sumber daya air dapat diwujudkan dengan bentuk melakukan konversi air menjadi energi listrik lebih baik dan efisien. Pembangkit Listrik Tenaga Mikrohidro (PLTMH) menjadi alternatif sumber energi listrik yang dapat dikembangkan saat ini. Dalam upaya ikut berpartisipasi pada sektor ketenagalistrikan nasional maka akan dibangun PLTMH yang berada di Desa Kebongembong Kecamatan Pageruyung Kabupaten Kendal. Unsur pokok dalam PLTMH meliputi air sebagai sumber energi, turbin dan generator. Sumber energi berupa air tersebut harus memiliki debit aliran serta tinggi jatuh air (head) tertentu, dimana hal ini akan menentukan besarnya daya listrik yang dihasilkan. Analisa ketersediaan air dan bangunan pengambilan PLTMH Kebongembong ini terletak di Sungai Lampir. Dalam menghitung potensi daya listrik yang mampu dihasilkan PLTMH akan menggunakan debit terkecil dari Q-90 dari Sungai Lampir yaitu sebesar 1,2 $\mathrm{m}^{3} /$ detik. Besarnya potensi daya listrik yang dapat dihasilkan oleh PLTMH Kebongembong yaitu sebesar $370 \mathrm{~kW}$.
\end{abstract}

Kata Kunci : Air, debit, daya listrik, PLTMH

\section{PENDAHULUAN}

Pertumbuhan penduduk dan peningkatan sosial ekonomi masyarakat, menyebabkan meningkatnya kebutuhan energi terutama di Pulau Jawa, yang sebagian besar dihasilkan dari instalasi pembangkit listrik tenaga pembakaran fosil. Sementara rasio elektrifikasi nasional tahun 2017 sudah mencapai 95\%, sehingga masih ada sekitar 5\% lokasi yang penduduknya belum dapat menikmati listrik (Kementerian ESDM, 2018). Pembangkit Listrik Tenaga Mikrohidro (PLTMH) menjadi alternatif sumber energi listrik yang dapat dikembangkan saat ini, khususnya di lokasi yang sulit dijangkau/pegunungan/perbukitan. Air menjadi sumber energi yang penting disaat sumber energi lain (bersumber dari fosil) mulai menipis, dikarenakan mampu menjadi sumber energi untuk pembangkit listrik mudah didapatkan, murah, terbaharukan serta tidak menimbulkan polusi. Letak Indonesia yang berada di daerah khatulistiwa menjadikannya sebagai negara yang memiliki kekayaan hutan hujan tropis, yang mana kondisi ini memberi potensi akan sumber daya air yang melimpah. Pengelolaan terhadap sumber daya air dapat diwujudkan dengan bentuk melakukan konversi air menjadi energi listrik lebih baik dan efisien. Dalam upaya ikut berpartisipasi pada sektor ketenagalistrikan nasional dan mendukung visi, misi serta strategi Pemda Kendal untuk meningkatkan pembangunan ekonomi yang berbasis potensi lokal serta meningkatkan kualitas pelayanan infrastruktur wilayah, maka Pemkab Kendal akan membangun PLTMH yang berada di Desa Kebongembong Kecamatan Pageruyung. 


\section{METODE}

Dalam melakukan analisa ketersediaan air/debit aliran yang menggunakan konversi curah hujan, maka dilakukan dahulu pengumpulan data curah hujan dan iklim (minimal 10 tahun terakhir) pada stasiun hujan dan klimatologi yang letaknya berada di sekitar lokasi rencana PLTMH. Kemudian melakukan digitasi daerah tangkapan (catchment area), sehingga diperoleh luasannya, di mana luasan tersebut akan dikalikan dengan tinggi air yang nantinya akan menghasilkan nilai debit. Dalam analisa debit menggunakan Metode Mock, terdapat parameter yang harus ditentukan seperti kondisi tutupan lahan, ketinggian air tanah (water soil storage) sehingga kita harus mencari melalui data yang ada (peta, studi terdahulu, pengamatan lapangan). Dalam penelitian ini ada nilai parameter yang berupa asumsi dikarenakan tidak memperoleh data yang sesuai. Tetapi nilai asumsi ini tentunya yang diperoleh melalui pendekatan ilmiah sehingga dapat merepresentasikan kondisi riil di lapangan.

Untuk menentukan potensi daya listrik yang akan dihasilkan, maka harus diketahui beda tinggi (head) jatuhnya air, yaitu antara masuknya air ke dalam bangunan pengambilan (intake) sampai dengan lokasi rumah turbin. Penentuan beda tinggi ini menggunakan desk study yaitu melalui pengamatan Peta Rupa Bumi dan Aplikasi Google Earth.

PLTMH merupakan jenis pembangkit listrik skala kecil dengan debit air yang tidak besar. Menurut Peraturan Menteri PUPR Nomor 09/PRT/M/2016, PLTMH yaitu pembangkit listrik yang memanfaatkan tenaga dari aliran/ terjunan air, waduk/bendungan, atau saluran irigasi yang pembangunannya bersifat multiguna dengan kapasitas kurang dari $1 \mathrm{MW}$ (satu Mega Watt).

Unsur pokok dalam PLTMH meliputi air sebagai sumber energi, turbin dan generator. Sumber energi berupa air tersebut harus memiliki debit aliran serta tinggi jatuh air (bead) tertentu, dimana hal ini akan menentukan besarnya daya listrik yang dihasilkan. Prinsip kerja PLTMH adalah memanfaatkan beda tinggi masuknya air hingga ke rumah turbin dan besarnya debit air yang ada pada aliran (Nugroho, 2015). Selanjutnya air masuk lewat bangunan intake/pipa pengambilan akan diteruskan oleh saluran pembawa hingga penstock, lalu menumbuk dan memutarkan poros turbin sehingga menghasilkan energi mekanik. Poros yang berputar selanjutnya dihubungkan ke generator dengan mengunakan kopling. Kemudian dari generator akan menghasilkan energi listrik yang akan masuk ke sistem kontrol arus listrik sebelum dialirkan untuk melayani kebutuhan listrik.

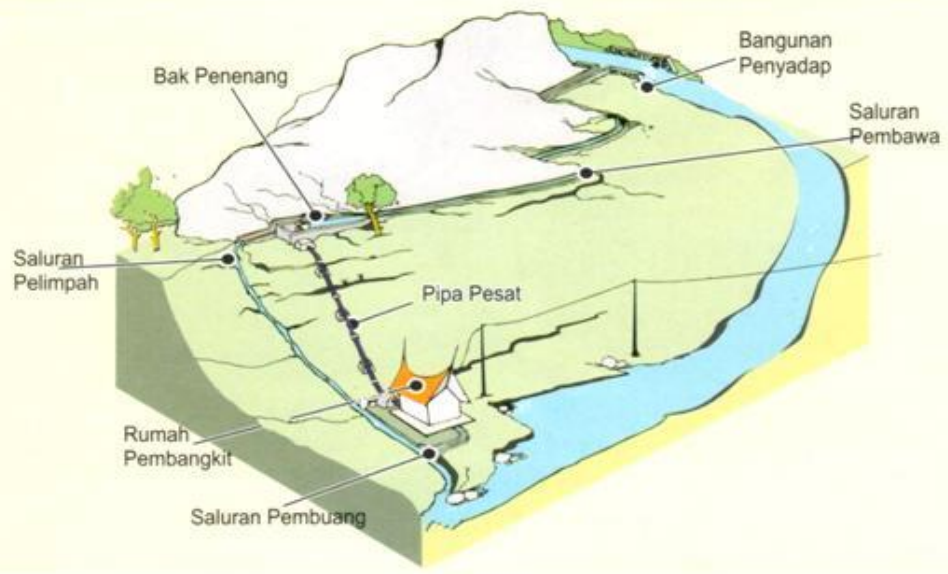

Gambar 1. Skema sistem PLTMH

Debit aliran air yang digunakan harus memiliki kontinuitas dan tingkat keandalan tertentu. Tingkat keandalan yaitu besarnya peluang/keandalan dari suatu besarnya debit yang terjadi pada suatu waktu. Keandalan debit yang digunakan untuk pembangkit listrik tenaga air yaitu Q-90 s.d Q-95 (Soemarto, 1999), artinya peluang terjadinya besaran debit sebesar 90\% s.d 95\%. Analisa ketersediaan air sangat penting karena akan dikombinasikan dengan tinggi jatuh (head) yang nantinya akan menentukan potensi daya listrik yang akan diperoleh.

Potensi air yang digunakan yaitu Sungai Lampir di Kabupaten Kendal. Terdapat keterbatasan dalam hal data debit dikarenakan di lokasi rencana PLTMH tidak terdapat alat pengukur debit, di mana alat pengukur berada dibagian hilirnya, sehingga dalam analisa debit andalan dilakukan dengan mengkonversi curah hujan yang jatuh dalam suatu 
daerah tangkapan air sesuai lokasi PLTMH (catchment area) menjadi debit. Debit andalan dapat dianalisa untuk periode setengah bulanan atau bulanan menggunakan Metoda Mock (Tahun 1973) berdasarkan atas siklus hidrologi, dimana analisa ini dipengaruhi oleh beberapa faktor yaitu curah hujan bulanan dan jumlah hari hujan; evapotranspirasi serta karakteristik hidrologi daerah tangkapan air (catchment area).

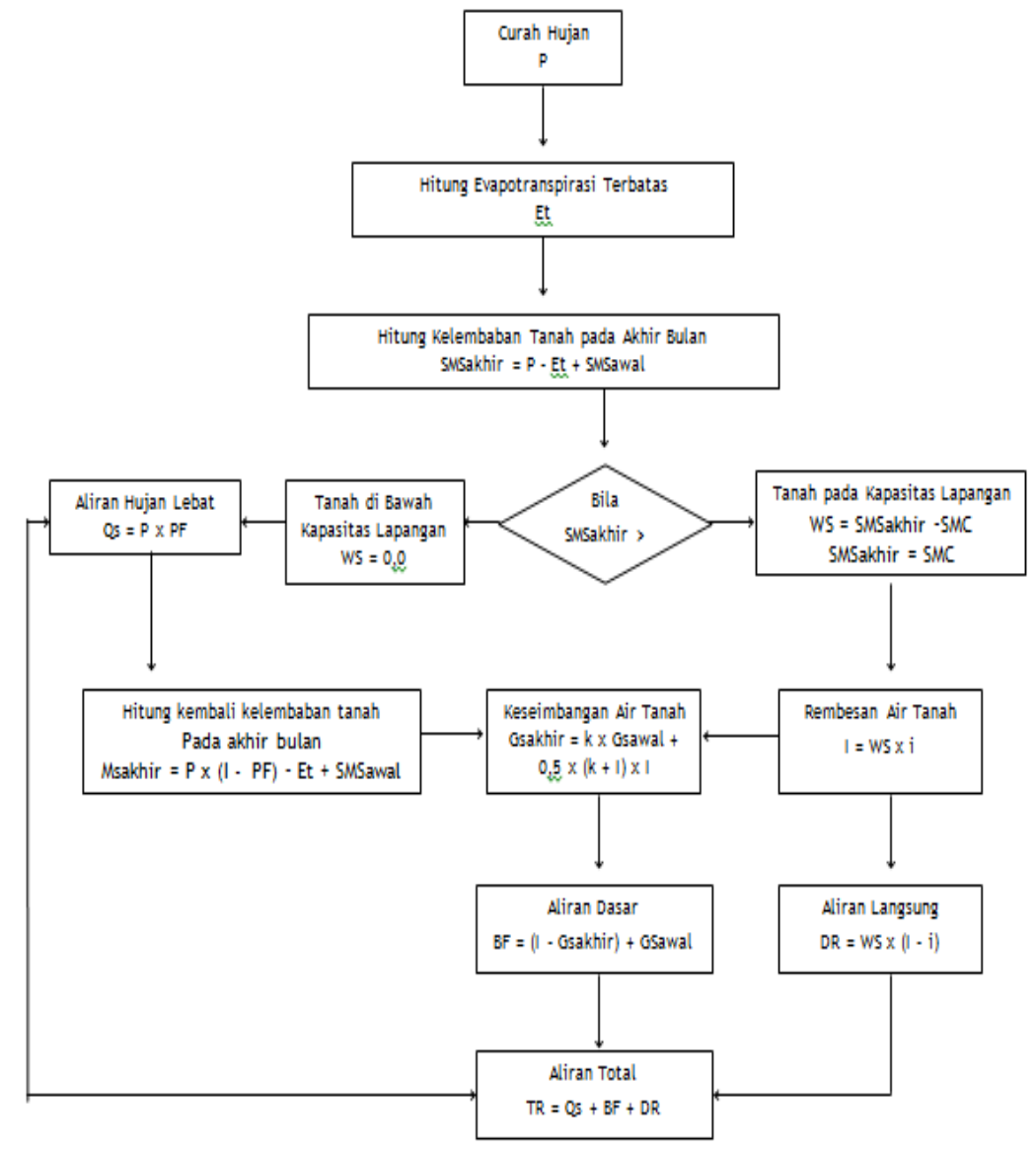

Gambar 2. Bagan alir model water balance metode mock

Dalam sistem PLTMH, potensi daya air dipengaruhi oleh debit aliran dan tinggi jatuh air (head). Semakin besar debit aliran air yang masuk, maka semakin besar pula daya yang dihasilkan. Kemudian semakin besar tinggi jatuh air, semakin besar pula tekanan yang dihasilkan air terhadap sudu turbin. Menurut Sukamta (2013), hubungan potensi daya air terhadap debit dan tinggi jatuh air dapat rumuskan dengan Persamaan (1).

$$
P_{\text {gross }}=\rho \cdot \mathrm{Q} \cdot \mathrm{g} \text {.]. }
$$

$\mathrm{P} \quad=$ potensi/daya yang dihasilkan (Watt)

Q = densitas air pada suhu T $\left(\mathrm{kg} / \mathrm{m}^{3}\right)$

$\mathrm{Q}=$ debit air $\quad\left(\mathrm{m}^{3} /\right.$ detik $)$

$\mathrm{g} \quad=$ percepatan gravitasi $\quad\left(\mathrm{m} /\right.$ detik $\left.^{2}\right)$

$\mathrm{H}=$ tinggi jatuh air (m)

Seletah melewati turbin dan generator, potensi daya air tersebut akan berkurang (Sukamta, 2013), yang diformulasikan melalui Persamaan (2).

\section{$P=\eta \cdot \rho . Q . g . H$}

$\begin{array}{lll}\mathrm{P} & =\text { potensi/daya yang dihasilkan } & (\mathrm{Watt}) \\ \mathrm{Q} & =\text { densitas air pada suhu } \mathrm{T} & \left(\mathrm{kg} / \mathrm{m}^{3}\right) \\ \mathrm{Q} & =\text { debit air } & \left(\mathrm{m}^{3} / \text { detik }\right)\end{array}$




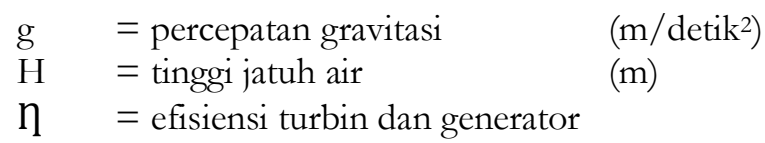

Kehilangan energi yang disebabkan adanya gesekan pada pipa pesat (penstock) dan pada turbin, menyebabkan berkurangnya daya yang dihasilkan oleh turbin dari daya kotornya $\left(P_{\text {gross }}\right)$. Kemudian kurang efisiennya sistem kerja dan generator juga menyebabkan daya yang keluar pada generator akan mengalami pengurangan lagi. Nilai efisiensi berkisar antara 0,8-0,95 (Sukamta, 2013).

\section{PEMBAHASAN}

Data hujan dan iklim sangat mutlak diperlukan dalam menganalisis ketersediaan air. Kemudian data yang digunakan dalam analisa ketersediaan air/debit andalan PLTMH Kebongembong berasal dari 3 stasiun hujan dan 1 stasiun klimatologi yaitu:

1. Stasiun Hujan Bawang/Sangubanyu (No.149)

2. Stasiun Hujan Tlogomili (No.12)

3. Stasiun Hujan Bawang (No. 148)

4. Stasiun Klimatologi Juwero

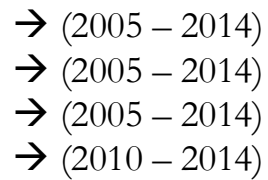

$\rightarrow(2010-2014)$

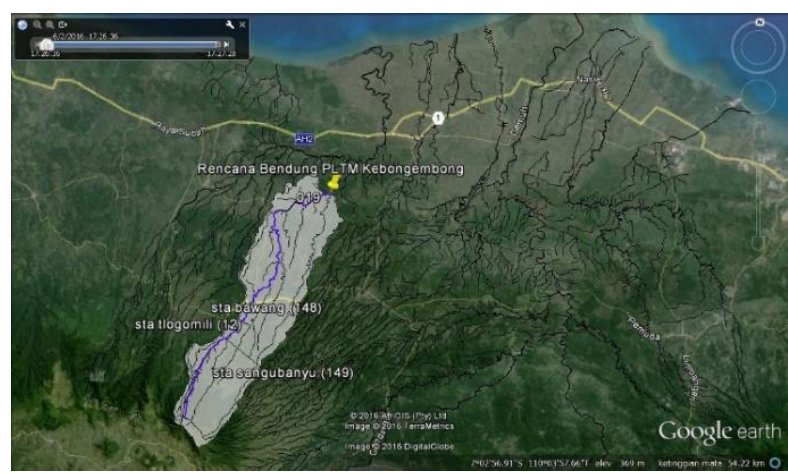

Gambar 3. Lokasi stasiun hujan dan catchement area rencana PLTMH

Kemudian untuk memperoleh pengaruh luasan dari tiap stasiun hujan terhadap daerah tangkapan air, maka dianalisa menggunakan Metode Thiesesen yang hasilnya dapat dilihat pada Tabel 1.

Tabel 1. Pengaruh stasiun hujan di catchment area PLTMH kebongembong dengan metode polygon thiessen

\begin{tabular}{cccc}
\hline \multirow{2}{*}{ NO } & \multirow{2}{*}{ STASIUN HUJAN } & \multicolumn{2}{c}{ POLYGON THIESSEN FACTOR } \\
& Prosentase ( \%) & Luas DAS ( KM $\left.\mathbf{~ K M}^{\mathbf{2}}\right)$ \\
\hline 1 & Stasiun Sangubanyu (No.149) & 30,8 & 31,5 \\
2 & Stasiun Tlogomili (No.12) & 69,2 & 70,7 \\
3 & Stasiun Bawang (No.12A) & - & - \\
\multicolumn{2}{c}{ Jumlah } & 100 & 102,2 \\
\hline
\end{tabular}

Dari hasil pengaruh stasiun hujan tersebut, dapat diperoleh curah hujan bulanan. Untuk lebih jelasnya mengenai hasil perhitungan hujan bulanan untuk daerah tangkapan air (catchement area) Kebongembong disajikan pada Tabel (2). 
Jurnal Matriks Teknik Sipil

DOI: https://doi.org/10.20961/mateksi.v8i3

ISSN: $2354-8630$

E-ISSN: 2723-4223

Vol 8, No 4 (2020): Desember

Tabel 2. Curah hujan bulanan di DTA Bendung Kebongembong

\begin{tabular}{|c|c|c|c|c|c|c|c|c|c|c|c|c|}
\hline \multirow{2}{*}{ Tahun } & \multicolumn{12}{|c|}{ CURAH HUJAN BULANAN (mm) } \\
\hline & Jan & Peb & Mar & Apr & Mei & Jun & Jul & Agt & Sep & Okt & Nop & Des \\
\hline 2005 & 421 & 546 & 609 & 410 & 146 & 171 & 222 & 22 & 124 & 452 & 315 & 604 \\
\hline Hari Hujan & 15 & 20 & 24 & 21 & 8 & 11 & 9 & 4 & 7 & 17 & 19 & 24 \\
\hline 2006 & 1033 & 655 & 429 & 528 & 406 & 72 & 10 & 0 & 0 & 25 & 133 & 462 \\
\hline Hari Hujan & 23 & 21 & 24 & 23 & 16 & 4 & 4 & 1 & 2 & 6 & 14 & 22 \\
\hline 2007 & 506 & 669 & 914 & 459 & 260 & 206 & 32 & 13 & 9 & 43 & 497 & 653 \\
\hline Hari Hujan & 21 & 24 & 22 & 24 & 13 & 9 & 1 & 2 & 1 & 7 & 19 & 24 \\
\hline 2008 & 1106 & 1336 & 601 & 639 & 394 & 260 & 21 & 107 & 76 & 359 & 781 & 877 \\
\hline Hari Hujan & 21 & 25 & 20 & 20 & 15 & 7 & 1 & 6 & 8 & 13 & 21 & 25 \\
\hline 2009 & 1028 & 1399 & 570 & 130 & 110 & 175 & 9 & 0 & 63 & 118 & 192 & 511 \\
\hline Hari Hujan & 24 & 25 & 18 & 10 & 12 & 9 & 1 & 3 & 3 & 11 & 15 & 14 \\
\hline 2010 & 811 & 553 & 416 & 330 & 291 & 358 & 199 & 132 & 451 & 549 & 544 & 591 \\
\hline Hari Hujan & 16 & 16 & 15 & 10 & 12 & 11 & 9 & 11 & 15 & 15 & 16 & 20 \\
\hline 2011 & 781 & 334 & 644 & 533 & 407 & 21 & 117 & 2 & 41 & 221 & 572 & 692 \\
\hline Hari Hujan & 24 & 22 & 22 & 23 & 17 & 6 & 6 & 1 & 9 & 14 & 19 & 25 \\
\hline 2012 & 1731 & 558 & 460 & 485 & 411 & 149 & 10 & 0 & 6 & 224 & 483 & 903 \\
\hline Hari Hujan & 27 & 22 & 23 & 19 & 16 & 8 & 2 & 0 & 3 & 11 & 22 & 23 \\
\hline 2013 & 753 & 888 & 743 & 487 & 168 & 413 & 378 & 46 & 21 & 120 & 397 & 678 \\
\hline Hari Hujan & 28 & 22 & 21 & 17 & 15 & 22 & 13 & 4 & 4 & 13 & 17 & 24 \\
\hline 2014 & 651 & 704 & 491 & 510 & 371 & 52 & 142 & 55 & 64 & 87 & 178 & 533 \\
\hline Hari Hujan & 28 & 23 & 20 & 17 & 11 & 10 & 15 & 6 & 1 & 5 & 16 & 24 \\
\hline Rata-rata Hujan & 921 & 713 & 574 & 396 & 256 & 215 & 156 & 34 & 118 & 280 & 417 & 663 \\
\hline Rata-rata Hari Hujan & 22 & 21 & 20 & 17 & 13 & 9 & 7 & 4 & 6 & 12 & 18 & 22 \\
\hline
\end{tabular}

Untuk data klimatologi disajikan pada Tabel (3).

Tabel 3. Data klimatologi rerata stasiun juwero tahun 2010 - 2014

\begin{tabular}{|c|c|c|c|c|c|c|c|c|c|c|c|c|c|}
\hline BULAN & SATUAN & JAN & PEB & MAR & APR & MEI & JUN & JUL & AGT & SEP & OKT & NOP & DES \\
\hline TEMPERATUR UDARA & $(\mathrm{oC})$ & 27,0 & 26,7 & 28,0 & 27,9 & 28,6 & 28,5 & 28,5 & 28,9 & 29,9 & 30,5 & 29,3 & 28,1 \\
\hline KELEMBABAN UDARA (RH) & $(\%)$ & 94,9 & 94,8 & 95,0 & 94,9 & 95,1 & 94,9 & 95,8 & 95,7 & 96,2 & 96,4 & 95,0 & 95,4 \\
\hline PENYINARAN MATAHARI & $(\%)$ & 21,4 & 42,0 & 32,8 & 50,5 & 63,8 & 58,0 & 67,1 & 78,3 & 80,9 & 69,8 & 48,9 & 31,5 \\
\hline KEC. ANGIN (Tinggi 2 M) & $(\mathrm{m} / \mathrm{dtk})$ & 0,6 & 0,7 & 0,6 & 0,5 & 0,7 & 0,6 & 0,7 & 0,7 & 0,7 & 0,7 & 0,5 & 0,5 \\
\hline
\end{tabular}

Dalam analisa debit andalan, diperlukan nilai evapotranspirasi yang terjadi pada catchment area. Evapotranspirasi adalah proses penguapan air yang ada pada permukaan dan tanaman. Evapotranspirasi terbatas (Et) diperoleh dari perhitungan evapotranspirasi potensial (Ep) menggunakan Metode Penman yang dijelaskan pada Tabel 4. 
Jurnal Matriks Teknik Sipil

DOI: https://doi.org/10.20961/mateksi.v8i3

ISSN: 2354-8630

E-ISSN: 2723-4223

Vol 8, No 4 (2020): Desember

Tabel 4. Nilai evapotranspirasi metode penman

\begin{tabular}{|c|c|c|c|c|c|c|c|c|c|c|c|c|c|c|}
\hline NO. & DASAR & UNIT & JAN & FEB & MAR & APR & MEI & JUNI & JULI & AGT & SEP & OKT & NOV & DES \\
\hline 1 & Suhu Udara & ${ }^{\circ} \mathrm{C}$ & 27,0 & 26,7 & 28,0 & 27,9 & 28,6 & 28,5 & 28,5 & 28,9 & 29,9 & 30,5 & 29,3 & 28,1 \\
\hline 2 & Kelembaban Relatif & $\%$ & 94,9 & 94,8 & 95,0 & 94,9 & 95,1 & 94,9 & 95,8 & 95,7 & 96,2 & 96,4 & 95,0 & 95,4 \\
\hline 3 & Kecepatan Angin (U) & $\mathrm{m} / \mathrm{s}$ & 0,6 & 0,7 & 0,6 & 0,5 & 0,7 & 0,6 & 0,7 & 0,7 & 0,7 & 0,7 & 0,5 & 0,5 \\
\hline 4 & Penyinaran Matahari 8 Jam (Q1) & $\%$ & 21,4 & 42,0 & 32,8 & 50,5 & 63,8 & 58,0 & 67,1 & 78,3 & 80,9 & 69,8 & 48,9 & 31,5 \\
\hline 5 & Letak Garis Lintang & derajat & 7,0 & 7,0 & 7,0 & 7,0 & 7,0 & 7,0 & 7,0 & 7,0 & 7,0 & 7,0 & 7,0 & 7,0 \\
\hline 6 & Transfer ke $12 \mathrm{Jam}=0,786 \mathrm{Q} 1+3,45$ & $\%$ & 20 & 36 & 29 & 43 & 54 & 49 & 56 & 65 & 67 & 58 & 42 & 28 \\
\hline \multicolumn{15}{|c|}{ Perhitungan (Prosida/Penman) } \\
\hline 7 & Tabel 2 dengan (1) & & 9,20 & 9,17 & 9,32 & 9,31 & 9,40 & 9,39 & 9,39 & 9,44 & 9,56 & 9,64 & 9,49 & 9,33 \\
\hline 8 & Tabel 2 dengan (1) & & 2,70 & 2,66 & 2,86 & 2,84 & 2,94 & 2,92 & 2,92 & 2,98 & 3,13 & 3,23 & 3,04 & 2,87 \\
\hline 9 & Tabel 2 dengan (1) & & 26,74 & 26,32 & 28,32 & 28,16 & 29,34 & 29,17 & 29,17 & 29,85 & 31,64 & 32,76 & 30,56 & 28,49 \\
\hline 10 & Tabel 2 dengan (1) & & 2,06 & 2,04 & 2,14 & 2,13 & 2,19 & 2,18 & 2,18 & 2,20 & 2,31 & 2,37 & 2,25 & 2,15 \\
\hline 11 & $(2) \times(9)$ & & 25,4 & 25,0 & 26,9 & 26,7 & 27,9 & 27,7 & 27,9 & 28,6 & 30,4 & 31,6 & 29,0 & 27,2 \\
\hline 12 & Tabel 3 dengan (11) & & 0,102 & 0,094 & 0,096 & 0,096 & 0,099 & 0,115 & 0,134 & 0,127 & 0,096 & 0,094 & 0,093 & 0,09 \\
\hline 13 & $(9)-(11)$ & & 1,35 & 1,36 & 1,40 & 1,45 & 1,44 & 1,49 & 1,24 & 1,29 & 1,22 & 1,19 & 1,53 & 1,32 \\
\hline 14 & Tabel 4 dengan (3) & & 0,141 & 0,151 & 0,141 & 0,132 & 0,151 & 0,141 & 0,151 & 0,151 & 0,151 & 0,151 & 0,132 & 0,132 \\
\hline 15 & $(13) \times(14)$ & & 0,19 & 0,20 & 0,20 & 0,19 & 0,22 & 0,21 & 0,19 & 0,19 & 0,18 & 0,18 & 0,20 & 0,17 \\
\hline 16 & Tabel 5 dengan (5) & & 9,12 & 9,16 & 8,90 & 8,32 & 7,64 & 7,25 & 7,37 & 7,95 & 8,59 & 8,99 & 9,06 & 9,06 \\
\hline 17 & Tabel 6 dengan (6) & & 0,30 & 0,36 & 0,33 & 0,38 & 0,43 & 0,41 & 0,44 & 0,47 & 0,48 & 0,44 & 0,38 & 0,33 \\
\hline 18 & $(16) \times(17)$ & & 2,69 & 3,28 & 2,94 & 3,20 & 3,25 & 2,95 & 3,21 & 3,73 & 4,10 & 3,99 & 3,44 & 2,95 \\
\hline 19 & $8 \times[1-(6)]$ & & 6,38 & 5,08 & 5,66 & 4,55 & 3,71 & 4,08 & 3,51 & 2,80 & 2,64 & 3,34 & 4,65 & 5,75 \\
\hline 20 & $1-[(19) / 10]$ & & 0,36 & 0,49 & 0,43 & 0,55 & 0,63 & 0,59 & 0,65 & 0,72 & 0,74 & 0,67 & 0,53 & 0,43 \\
\hline 21 & $(7) \times(12) \times(20)$ & & 0,34 & 0,42 & 0,39 & 0,49 & 0,59 & 0,64 & 0,82 & 0,86 & 0,68 & 0,60 & 0,47 & 0,36 \\
\hline 22 & $(18)-(21)$ & & 2,35 & 2,86 & 2,55 & 2,71 & 2,66 & 2,31 & 2,39 & 2,87 & 3,43 & 3,38 & 2,96 & 2,60 \\
\hline 23 & $(8) \times(22)$ & & 6,35 & 7,60 & 7,29 & 7,70 & 7,83 & 6,76 & 6,98 & 8,56 & 10,72 & 10,93 & 9,01 & 7,45 \\
\hline 24 & $(15)+(23)$ & & 6,54 & 7,81 & 7,49 & 7,89 & 8,05 & 6,96 & 7,17 & 8,75 & 10,91 & 11,11 & 9,22 & 7,63 \\
\hline 25 & $(24):(10)$ & $\mathrm{mm} /$ hari & 3,17 & 3,83 & 3,50 & 3,71 & 3,67 & 3,19 & 3,29 & 3,98 & 4,72 & 4,69 & 4,10 & 3,55 \\
\hline 26 & Jumlah Hari & hari & 31 & 28 & 31 & 30 & 31 & 30 & 31 & 31 & 30 & 31 & 30 & 31 \\
\hline 27 & Evapotranspirasi Potensial (Eto) & $\mathrm{nm} /$ bulan & 98 & 107 & 109 & 111 & 114 & 96 & 102 & 123 & 142 & 145 & 123 & 110 \\
\hline
\end{tabular}

Untuk perhitungan ketersediaan air Sungai Lampir (lokasi rencana PLTMH Kebongembong), dalam kajian ini mengambil titik kontrol yaitu di rencana bangunan pengambilan/bendung Kebongembong. Pemilihan titik tersebut dikarenakan bendung ini merupakan bangunan pengambilan/ intake dari power house, sehingga bisa diketahui besarnya ketersediaan air untuk semua yang akan dimanfaatkan untuk menggerakkan turbin di power house. Metode dalam analisa debit andalan ini menggunakan Metode Mock, yaitu dengan menghitung besarnya debit bulanan yang dipengaruhi oleh curah hujan bulanan dan hari hujan, karakteristik tutupan lahan, evapotranspirasi (Metode Penman), kapasitas kandungan air tanah (Soil Moisture Capacity = SMC) dan tampungan kelembaban air tanah (Soil Moisture Storage $=S M S$ ).

Dalam analisa debit andalan Metode Mock, untuk setiap bulannya, pertama-tama dihitung tampungan kelembaban air tanah (SMS) yang terjadi pada akhir bulan. Apabila SMS pada akhir bulan tersebut lebih besar dari kapasitas kandungan air tanah (SMC), artinya ada kelebihan air (Water Surplus $=$ WS). Lalu apabila SMS pada akhir bulan lebih kecil dari SMC, maka tidak ada kelebihan air (WS =0). Akan tetapi meskipun tidak ada kelebihan air, bisa dimungkinkan terjadinya aliran langsung (run off), di mana hal ini diakibatkan oleh limpasan hujan lebat (storm run off). Debit andalan sebagai bentuk ketersediaan air dengan peluang (Q-90) dapat dilihat pada Tabel (5).

Tabel 5. Debit andalan Q-90 sungai lampir

\begin{tabular}{|c|c|c|c|c|c|c|c|c|c|c|c|c|c|}
\hline \multirow{2}{*}{ KEANDALAN } & \multicolumn{12}{|c|}{ Debit (m3/detik) } & \multirow{2}{*}{ Rerata } \\
\hline & Jan & Feb & Mar & Apr & Mei & Jun & Jul & Ags & Sep & Okt & Nov & Des & \\
\hline Q90 & 7,0 & 10,2 & 12,9 & 11,8 & 8,1 & 7,1 & 7,7 & 4,5 & 3,6 & 1,9 & 1,2 & 6,0 & 6,82 \\
\hline
\end{tabular}

Untuk grafik debit andalan Q-90 Sungai Lampir dapat dilihat pada Gambar (4). 


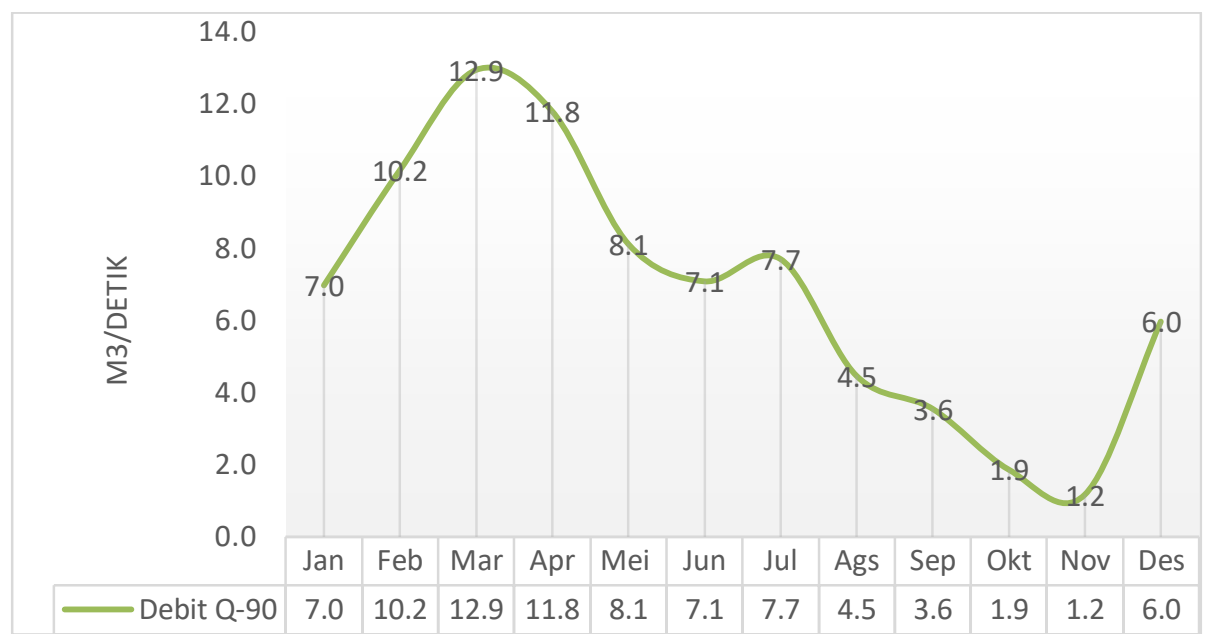

Gambar 4. Grafik debit andalan Q-90 sungai lampir

Penjelasan dari tabel dan gambar di atas yaitu Sungai Lampir memiliki debit rata-rata bulanan dengan keandalan Q-90 sebesar 6,82 $\mathrm{m}^{3} /$ detik. Sedangkan debit terkecil dari Q-90 Sungai Lampir terjadi pada Bulan November. Dalam merencanakan PLTMH, debit yang diperlukan yaitu debit yang konstan agar pasokan tenaga listrik dari turbin yang digerakan oleh air dapat berjalan secara kontinyu. Sehingga dalam menghitung potensi daya listrik yang dapat dihasilkan akan menggunakan debit terkecil dari Q-90 yaitu sebesar 1,2 m³/detik.

Dari hasil pengamatan Peta Rupa Bumi dan digitasi pada Google Earth, beda tinggi elevasi (head) antara bangunan pengambilan dengan rumah turbin mencapai $35 \mathrm{~m}$, dengan nilai efisiensi turbin dan generator sebesar 0,9 . Kemudian dengan nilai percepatan gravitasi sebesar 9,81 m/detik2 dan densitas/massa jenis air sebesar 1000 $\mathrm{kg} / \mathrm{m} 3$, maka besarnya daya listrik yang dapat dihasilkan oleh PLTMH Kebongembong dapat diuraikan pada perhitungan bawah ini.

$$
\begin{aligned}
\mathrm{P} & =\eta \text { @.Q.g.H } \\
\mathrm{P} & =0,9 \times 1000 \times 1,2 \times 9,81 \times 35 \\
& =370.818 \text { Watt } \\
& =370 \mathrm{~kW}
\end{aligned}
$$

Sehingga potensi daya listrik yang dapat dihasilkan oleh PLTMH Kebongembong yaitu sebesar $370 \mathrm{~kW}$.

\section{SIMPULAN}

Berdasarkan hasil kajian dan studi terhadap rencana pembangunan PLTMH Kebongembong, dapat diperoleh hasil:

1. Ketersediaan air atau debit andalan Q-90 Sungai Lampir diambil pada nilai terkecil yaitu sebesar 1,2 $\mathrm{m}^{3} /$ detik. Hal ini bertujuan untuk menjaga kontinuitas besarnya debit yang akan mempengaruhi besarnya daya listrik yang akan dihasilkan.

2. Sesuai besarnya ketersediaan air, maka daya listrik yang dapat dihasilkan dari PLTMH Kebongembong sebesar $370 \mathrm{~kW}$. Tentunya besarnya daya ini harus digunakan secara optimal untuk memenuhi kebutuhan listrik masyarakat disekitar lokasi yang memang benar-benar belum menikmati listrik dikarenakan sulitnya lokasi untuk diakses, sehingga dengan adanya sumber listrik yang dekat maka dapat dimanfaatkan dengan baik.

3. Perlu dipertimbangkan untuk memasang alat turbin lebih dari satu. Hal ini bertujuan apabila sewaktu kondisi debit aliran besar (yaitu di musim penghujan) maka turbin yang bekerja menyesuaikan dengan besarnya debit yang ada, sehingga memperbesar daya listrik yang dihasilkan.

\section{UCAPAN TERIMAKASIH}

Ucapan terima kasih penyusun sampaikan kepada Dinas PUSDATARU Provinsi Jawa Tengah dan PT. Pantarei Listrik Tirta Anugrah yang telah berkenan memberikan data, informasi dan waktu untuk berdiskusi, serta kepada seluruh pihak yang membantu sehingga penyusun dapat menyelesaikan penelitian ini. 


\section{REFERENSI}

Dinas Pekerjaan Umum Sumber Daya Air dan Penataan Ruang Provinsi Jawa Tengah, 2017, "Data Curah Hujan Harian dan Klimatologi: Seksi Data dan Informasi Sumber Daya Air".

Kementrian Energi Dan Sumber Daya Mineral, 2017, “Kajian Supply Demand Energi”, Kementrian ESDM. Jakarta.

Kementerian Pekerjaan Umum Dan Perumahan Rakyat, 2016, "Peraturan Menteri Pekerjaan Umum Dan Perumahan Rakyat Republik Indonesia Nomor 09/Prt/M/2016 Tentang Tata Cara Pelaksanaan Kerjasama Pemerintah Dan Badan Usaha Dalam Pemanfaatan Infrastruktur Sumber Daya Air Untuk Pembangunan Pembangkit Listrik Tenaga Air/Pembangkit Listrik Tenaga Minihidro/Pembangkit Listrik Tenaga Mikrohidro", Biro Hukum Kementerian Pekerjaan Umum Dan Perumahan Rakyat.

Kodotie, JR. Syarief, Roestam, 2005, "Pengelolaan Sumber Daya Air Terpadu", Andi Offset. Yogyakarta

Nugroho Y.S.H., Hunggul; M. Kudeng Sallata, 2015, "PLTMH (Pembangkit Listrik Tenaga Mikro Hidro) Panduan Lengkap Membuat Sumber Energi Terbarukan Secara Swadaya", Andi Offset. Yogyakarta

Soemarto, 1999, "Hidrologi Teknik Edisi ke-2", Erlangga. Jakarta.

Sukamta S, Kusmantoro A., 2013, "Perencanaan pembangkit listrik tenaga mikrohidro (PLTMH) Jantur Tabalas Kalimantan Timur", Jurnal Teknik Elektro. 